\title{
Pengelolaan, Pengawasan Kawasan Pesisir dan Laut di Indonesia
}

\author{
Hasan Basri ${ }^{1}$ \\ Dosen Fakultas Hukum Universitas Malikussaleh
}

\begin{abstract}
This research is a literature study on the management and supervision of coastal and marine areas in Indonesia. The results showed that coastal and marine areas with their natural resources have an important meaning for economic development, because coastal and marine areas are areas with biological and nonbiological resources that are very productive. In addition, coastal and marine areas still have a number of critical problems related to ecological, socio-economic and institutional issues. Ecological problems can be observed from the phenomenon of damage to coral reefs, mangrove forests, pollution, overfishing, coastal abrasion and physical degradation of other coastal habitats. It is essentially aimed at empowering the socioeconomy of the community, so the community should have contributed to organize themselves in managing coastal and marine resources in this autonomy era. The process of transferring power from government to society must be realized. However, there are a number of things that are still the responsibility of the government, such as matters of fiscal resources policy, development of facilities and infrastructure, preparation of coastal spatial planning, and resource management legal instruments. Even though this is part of the government's authority, it does not mean that the community does not have the contribution and participation in every policy formulation. With the contribution and participation of the community, the formulated policy will touch more on the real issue and not harm the public interest.
\end{abstract}

Key Words : Management, Supervision, Coastal, Ocean

Abstrak

Karya ini merupakan studi pustaka tentang pengelolaan dan pengawasan kawasan pesisir dan laut di Indonesia. Hasil penelitian menunjukkan bahwa wilayah pesisir dan kelautan dengan sumber daya alamnya memiliki arti penting bagi pembangunan ekonomi, karena kawasan pesisir dan kelautan merupakan kawasan dengan sumber hayati dan non hayati yang sangat produktif. Di samping itu, wilayah pesisir dan kelautan masih terdapat sejumlah permasalahan kritis yang berkaitan dengan masalah ekologi, sosial ekonomi serta kelembagaan. Permasalahan ekologi dapat dicermati dari fenomena rusaknya terumbu karang, hutan mangrove, pencemaran, tangkap lebih, abrasi pantai serta penurunan fisik habitat pesisir lainnya. Dalam pelaksanaan pengelolaan sumberdaya pesisir dan laut di pada hakikatnya ditujukan untuk memberdayakan sosial ekonomi masyarakat maka masyarakat seharusnya memiliki kekuatan besar untuk mengatur dirinya sendiri dalam pengelolaan sumberdaya pesisir dan laut di era otonomi ini. Proses peralihan kewenangan dari pemerintah ke masyarakat harus dapat diwujudkan. Namun ada beberapa hal yang masih menjadi tanggung jawab pemerintah seperti soal kebijakan fiskal sumberdaya, pembangunan sarana dan prasarana, penyusunan tata ruang pesisir, serta perangkat hukum pengelolaan sumberdaya Meski hal tersebut menjadi bagian dari kewenangan pemerintah, namun tidak berarti masyarakat tidak memiliki kontribusi dan partisipasi dalam setiap formulasi kebijakan. Dengan adanya kontribusi dan partisipasi masyarakat maka kebijakan yang diformulasikan tersebut akan lebih menyentuh persoalan yang sebenarnya dan tidak merugikan kepentingan publik.

Kata Kunci: Pengelolaan, Pengawasan, Pesisir, Lautan 


\section{A. PENDAHULUAN}

Pengaturan pengelolaan wilayah pesisir dan laut (Integrated coastal management) berdasarkan pada Chapter 17 Agenda 21, Deklarasi Johannesburg 2002, Plan of Implementation of the World Summit on Sustainable Development, 2002, dan Bali Plan of Action 2005 Integrated coastal management merupakan pedoman dalam pengaturan pemanfaatan dan pengelolaan sumberdaya alam di wilayah pesisir dan laut dengan memperhatikan lingkungan. Implementasi integrated coastal management dilakukan sebagai upaya untuk mengatasi konflik dalam pemanfaatan sumberdaya di wilayah pesisir dan laut, dan tumpang tindih kewenangan serta benturan kepentingan antar sektor.

Integrated coastal management berisi prinsip-prinsip dalam pengelolaan wilayah pesisir dan laut sebagaimana di atur dalam Agenda 21 Chapter 17 Program (a), Pemerintah Indonesia pada tahun 1995 telah menyusun Agenda 21-Indonesia, dalam Bab 18 tentang Pengelolaan Terpadu Daerah Pesisir dan Laut. Disebutkan bahwa orientasi pembangunan dan pengelolaan wilayah pesisir dan laut menjadi prioritas pengembangan, khususnya yang mencakup aspek keterpaduan dan kewenangan kelembagaannya, sehingga diharapkan sumberdaya yang terdapat di kawasan ini dapat menjadi produk unggulan dalam pembangunan bangsa Indonesia di abad mendatang (Agenda: 1997).

Perbedaan pemahaman pengaturan tentang pengelolaan wilayah pesisir dan laut di Indonesia memunculkan banyak konflik diantara para pengguna wilayah tersebut dan daerah-daerah kabupaten/kota yang berbatasan. Kemajemukan peraturan perundangan-undangan sangat potensial menimbulkan terjadinya konflik norma. Upaya melakukan integrasi terhadap pelaksanaan pengelolaan wilayah pesisir adalah melalui sinkronisasi pengaturan perundangan-undangan dalam pengelolaan wilayah pesisir dan laut.

Sumberdaya alam pesisir dan laut, dewasa ini sudah semakin disadari banyak orang bahwa sumberdaya ini merupakan suatu potensi yang cukup menjanjikan dalam mendukung tingkat perekonomian masyarakat terutama bagi nelayan. Konsekuensi logis dari sumberdaya pesisir dan laut sebagai 
sumberdaya milik bersama (common property) dan terbuka untuk umum (open acces) maka pemanfaatan sumberdaya alam pesisir dan laut dewasa ini semakin meningkat di hampir semua wilayah. (Churchill, 1999)

Seiring dengan meningkatnya usaha penangkapan dalam memenuhi kebutuhan pangan baik bagi masyarakat di sekitarnya maupun terhadap permintaan pasar antar pulau dalam negeri dan luar negeri, mengatakan bahwa perkembangan eksploitasi sumberdaya alam laut dan pesisir dewasa ini (penangkapan, budidaya, dan ekstraksi bahanbahan untuk keperluan medis) telah menjadi suatu bidang kegiatan ekonomi yang dikendalikan oleh pasar (market driven) terutama jenis-jenis yang bernilai ekonomis tinggi, sehingga mendorong eksploitasi sumberdaya alam laut dan pesisir dalam skala dan intensitas yang cukup besar.

$$
\text { Sebagai akibatnya }
$$

pemanfaatannya cenderung melebihi daya dukung sumberdaya (over eksploitation) dan bersifat destruktif. Kondisi ini semakin diperparah oleh peningkatan jumlah armada penangkapan, penggunaan alat dan teknik serta teknologi penangkapan yang tidak ramah lingkungan. Disamping itu berbagai aktivitas manusia baik di wilayah pesisir dan laut serta kegiatan di daratan (upland) yang juga dapat menimbulkan dampak pencemaran lingkungan. Kondisi ini menimbulkan tekanan lingkungan bahkan cenderung merusak sumberdaya alam pesisir dan laut yang cenderung meningkat intensitasnya dari waktu kewaktu, sehingga pada akhirnya menimbulkan menurunnya daya dukung sumberdaya dan dalam jangka panjang akan mengakibatkan suatu tragedi bersama (open tragedy). (Arifin, 2004)

Namun demikian, hingga saat ini tingkat pemanfaatan sumberdaya pesisir dan kelautan masih jauh dari tingkat optimal dan berkelanjutan, sehingga diperlukan upaya yang secara terus menerus dalam rangka pengelolaan dan pemanfaatan yang lebih optimal. Kondisi ini umumnya terjadi karena: (Arifin, 2004)

a. Kebijakan nasional cenderung bias pada sektor pertanian di luar perikanan laut, dimana programprogram pengamanan penyediaan bahan pangan bagi masyarakat memberi bobot yang sangat kecil, bahkan dapat dikatakan 
mengabaikan sumberdaya pesisir dan perikanan. Prioritas kebijakan ekonomi pemerintah agaknya juga bias pada ekonomi daratan, dimana sektor-sektor yang terkait dengan pesisir belum menjadi prioritas utama untuk ditumbuh kembangkan secara optimal bagi peningkatan kesejahteraan masyarakat dan memberikan kontribusi yang signifikan bagi pembangunan ekonomi nasional.

b. Faktor kedua adalah pembangunan produksi perikanan didominasi oleh penerapan usaha efisiensi penangkapan dan penerapan teknologi, dibanding pendekatan yang mempromosikan cara-cara pemanfaatan dan pengelolaan yang berkelanjutan.

Akibatnya, kebijakan maupun program yang diselenggarakan kurang komprehensif menjangkau isu-isu seperti kemiskinan, pengamanan penyediaan pangan bagi masyarakat, berkelanjutan, dan kesesuaian usaha tersebut terhadap kemampuan lingkungan.

c. Ketiga, kerusakan ekosistem sumberdaya pesisir dan kelautan di Indonesia pada umumnya terjadi karena kesadaran publik yang masih rendah. Disatu sisi karena pemerintah baik di tingkat pusat maupun di tingkat lokal, belum banyak menyadari wewenang dan tanggung jawab mereka dalam pengelolaan sumberdaya pesisir dan kelauatan. Selain itu, isu-isu pesisir dan kelauatan belum menjadi prioritas pemerintah maupun masyarakat umum dibanding pengelolaan sektor daratan seperti pertanian dan kehutanan.

Bila dilihat Selama ini, kawasan pesisir dan kelautan belum mendapat perhatian yang cukup serius baik dari pemerintah, masyarakat maupun pihak ketiga dalam pengelolaannya. Sehingga belakangan ini baru dirasakan berbagai permasalahan yang muncul tentang kawasan pesisir dan kelautan. Salah satu konsep penanganan kawasan pesisir yang dikembangkan adalah konsep Integrated Coastal Zone Management, yaitu pengelolaan wilayah pesisir dan kelautan secara terpadu dengan memperhatikan segala aspek terkait di pesisir yang meliputi antara lain aspek ekonomi, sosial, lingkungan dan teknologi. Melalui aplikasi konsep tersebut diharapkan dapat diatasi berbagai permasalahan yang muncul 
belakangan ini dalam pengelolaan, pengawasan kawasan pesisir dan kelautan. Beberapa permasalahan dalam pengelolaan dan pemanfaatan kawasan pesisir dan kelautan antara lain adalah: (bunghatta.ac.id )

1. Belum diatur dengan peraturan perundang-undangan.

2. Bersifat sektoral.

3. Belum dikelola sebagai satu kesatuan ekosistem.

4. Belum dipahaminya kewenangan Daerah Otonom oleh seluruh stakeholders.

Memperhatikan

permasalahan dalam pengelolaan dan pemanfaatan kawasan pesisir tersebut maka menjadi suatu kewajiban Pemerintah Kabupaten dan Kota yang ada di Provinsi Aceh untuk mengatur dalam sebuah produk hukum Mengenai Pengelolaan, Pengawasan Kelautan dan Pesisir. Hal tersebut tersebut tentu sejalan dengan implementasi kebijakan

Otonomi Daerah dan program nasional untuk membangun "poros maritim dunia" dalam rangka untuk mewujudkan program penataan kembali fungsi, pengelolaan dan pengawasan pesisir dan kelautan yang ada di Aceh.

\section{B. IDENTIFIKASI MASALAH}

Metode penelitian yang digunakan dalam penulisan ini dilakukan dengan studi literatur. Tipe penelitiannya adalah penelitian hukum (legal research). Pengertian penelitian hukum (legal research) dalam hal ini adalah penelitian yang dilakukan dengan mengkaji dan menganalisa substansi peraturan perundang-undangan atas pokok permasalahan. ( Peter, 2005) Dengan penelitian hukum (legal research) maka akan diperoleh preskripsi hukum yang dapat dipertanggungjawabkan secara ilmiah. Selain itu, penulisan ini disusun dengan menggunakan pendekatan perundang-undangan (statute approach). Pendekatan perundang-undangan dilakukan dengan menelaah semua undangundang dan semua regulasi yang bersangkutan dengan kebijakan mengenai Pengelolaan, Pengawasan Kelautan dan Pesisir.

\section{Dasar Hukum Pengelolaan Wilayah Pesisir dan Laut di Indonesia}

$$
\text { Indonesia sebagai negara }
$$

hukum, termasuk kategori negara hukum modern. Konsepsi negara hukum modern secara konstitusional 
dapat dirujuk pada rumusan tujuan negara yaitu: melindungi segenap bangsa Indonesia dan seluruh tumpah darah Indonesia, memajukan kesejahteraan umum, mencerdaskan kehidupan bangsa serta mewujudkan keadilan sosial. Normalisasi tujuan negara tersebut, khususnya memajukan kesejahteraan umum dan mewujudkan keadilan sosial antara lain termuat dalam Pasal 33 UUD 1945. Pasal 33 UUD 1945 sebagai dasar hak penguasaan negara mengatur tentang dasar-dasar sistem perekonomian dan kegiatan perekonomian yang dikehendaki dalam negara Indonesia, tetapi Pasal 33 bukan sebagai sesuatu yang berdiri sendiri, melainkan berkaitan dengan kesejahteraan sosial. Berdasarkan pemikiran yang demikian, maka upaya memahami Pasal 33 tidak terlepas dari dasar pemikiran tentang kesejahteraan. Atas dasar itu pula, sehingga tujuan hak penguasaan negara atas sumberdaya alam ialah keadilan sosial dan sebesar-besarnya kemakmuran rakyat.

Keterkaitan hak penguasaan negara dengan sebesar-besarnya kemakmuran rakyat) akan mewujudkan kewajiban Negara. (Abrar: 2004)
1. Segala bentuk pemanfaatan (bumi dan air) serta hasil yang di dapat (kekayaan alam), harus secara nyata meningkatkan kemakmuran dan kesejahteraan masyarakat;

2. Melindungi dan menjamin segala hak-hak rakyat yang terdapat di dalam atau di atas bumi, air dan berbagai kekayaan alam tertentu yang dapat dihasilkan secara langsung atau dinikmati oleh rakyat;

3. Mencegah segala tindakan dari pihak manapun yang akan menyebabkan rakyat tidak mempunyai kesempatan atau akan kehilangan haknya dalam menikmati kekayaan alam.

Dalam Undang-undang Nomor 27 Tahun 2007 tentang Pengelolaan Wilayah Pesisir dan Pulau-pulau Kecil (selanjutnya disebut PWP-PK) Pasal 1 Ayat (2), disebutkan bahwa: "Wilayah pesisir adalah daerah peralihan antara ekosistem darat dan laut yang dipengaruhi oleh perubahan di darat dan laut". Selanjutnya, pada Pasal 2 Undang-undang Nomor 27 Tahun 2007 tentang PWP-PK disebutkan bahwa: "Ruang lingkup pengaturan wilayah pesisir dan pulau-pulau kecil meliputi daerah peralihan antara 
ekosistem darat dan laut yang dipengaruhi oleh perubahan di darat dan laut, ke arah darat mencakup wilayah administrasi kecamatan dan ke arah laut sejauh 12 (dua belas) mi laut di ukur dari garis pantai."

$$
\text { Ruang lingkup Undang- }
$$

undang Nomor 27 Tahun 2007 tentang PWP-PK meliputi daerah pertemuan antara pengaruh perairan dan daratan, ke arah daratan mencakup wilayah administrasi kecamatan dan ke arah perairan laut sejauh 12 (dua belas) mil laut diukur dari garis pantai ke arah laut lepas dan/atau ke arah perairan kepulauan. Sementara itu, menurut UNCLOS 1982, pengertian/batasan wilayah pesisir tidak diatur, tetapi UNCLOS 1982, membagi laut ke dalam zonazona yaitu (Churchill: 1999):

a. Wilayah laut yang berada di bawah yurisdiksi suatu Negara adalah :

1. Perairan Pedalaman (Internal Waters)

2. Perairan Kepulauan (Archipelagic Waters)

3. Laut Wilayah (Territorial Sea)

4. Zona Tambahan (Contiguous Zone)

5. Zona Ekonomi Eksklusif (Exclusive Economic Zone)

\author{
6. Landas Kontinen (Continental \\ Shelf))
}

b. Wilayah laut yang berada di luar yurisdiksi suatu Negara adalah:

1. Laut Lepas (High Seas)

2. Dasar Laut Dalam/kawasan (Area/Deep Sea Bed)

Penentuan batas wilayah pesisir dan laut tidak dapat disamakan antara ketentuan dalam UU Nomor 27 Tahun 2007 tentang PWP-PK dengan UNCLOS 1982. UU Nomor 27 Tahun 2007 berlaku pada batas wilayah administrasi kecamatan dan ke arah laut sejauh 12 (dua belas) mil diukur dari garis pantai, sedangkan UNCLOS 1982 tidak menentukan batas wilayah pesisir maupun cara pengukurannya. Karakteristik, pengertian dan batasan wilayah pesisir di setiap negara berbedabeda, tergantung kondisi geografisnya. Pada umumnya karakteristik umum wilayah pesisir dan laut adalah sebagai berikut (Rohmin: 2003):

1. Laut merupakan sumber dari "common property resources" (sumberdaya milik bersama), sehingga memiliki fungsi publik / kepentingan umum;

2. Laut merupakan "open access", memungkinkan siapapun untuk 
memanfaatkan ruang laut untuk berbagai kepentingan;

3. Laut bersifat "fluida", dimana sumberdaya (biota laut) dan dinamika hydrooceanography tidak dapat disekat /dikapling;

4. Pesisir merupakan kawasan yang strategis karena memiliki topografi yang relatif mudah dikembangkan dan memiliki akses yang sangat baik (dengan) memanfaatkan laut sebagai "prasarana" pergerakan);

5. Pesisir merupakan kawasan yang kaya akan sumberdaya alam, baik yang terdapat di ruang daratan maupun ruang lautan, yang dibutuhkan untuk memenuhi kebutuhan manusia.

Dalam satu dekade belakangan ini banyak pihak berkepentingan yang memanfaatkan suberdaya kelautan dan pesisir dari jenis yang sama atau wilayah pesisir dan laut yang sama khususnya diwilayah yang pembangunannya pesat. Masingmasing pihak berkepentingan memegang dasar hukum, peraturan dan kebijakan dari instansi pusat yang berwenang. Kebijakan tersebut memuat maksud, tujuan, dan target dalam memanfaatkan sumber daya laut dan pesisir. Era otonomi daerah telah mendorong pemerintah daerah / kabupaten untuk menggali potensi ekonomi secara optimal untuk membiayai kegiatan pembangunan daerah. Namun harus diwaspadai agar kebijakan pengelolaan, pengawasan dan pemanfaatan potensi sumberdaya pesisir dan laut tetap bersandar pada kepantingan publik dan kelestarian lingkungan.

Oleh sebab itu Pengawasan dan pengendalian terhadap pesisir dan kelautan dilakukan untuk (Danial: 2012):

1. Mengetahui adanya penyimpangan pelaksanaan rencana strategis, rencana zonasi, rencana pengelolaan, serta implikasi penyimpangan tersebut terhadap perubahan kualitas ekosistem pesisir;

2. mendorong agar pemanfaatan sumberdaya pesisir dan kelautan sesuai dengan rencana pengawasan dan pengelolaannya;

3. memberikan sanksi terhadap pelanggar, baik berupa sanksi administrasi seperti pembatalan izin atau pencabutan hak, sanksi perdata seperti pengenaan denda atau ganti rugi; maupun sanksi pidana berupa penahanan ataupun kurungan. 
4. Dasar hukum tentang Pengelolaan Wilayah Pesisir dan kelautan ini merupakan landasan penyesuaian dengan ketentuan yang tercantum dalam peraturan perundang-undangan yang lain.

Untuk mencapai kebijakan tersebut, setiap instansi menyusun perencanaan sendiri, sesuai dengan tugas dan fungsi sektornya. Namun kurang mengakomodir kepentingan sektor lain, daerah dan masyarakat setempat dan lingkungannya. Perbedaan tujuan, sasaran dan rencana memicu kompotisi pemanfaatan dan tumpang tindih pengelolaan. Tumpang tindih perencanaan dan kompetisi pemanfaatan memicu konflik pemanfaatan. Perencanaan sektoral tersebut tidak bisa dikoordinasikan Pemerintah Daerah karena ada kewenangannya diperairan laut. Melihat situasi ini maka sangat tepat apabila Pemerintah Kabupaten dan Kota yang di Provinsi Aceh membuat suatu landasan hukum terkait dengan Pengelolaan, Pengawasan Kelautan dan Pesisir.

Adanya degradasi lingkungan pesisir dan laut. Pada awal tahun 80an, banyak pihak yang tersentak setelah menyaksikan kebijakan pembangunan yang hanya mengejar pertumbuhan ekonomi dan produktivitas ternyata telah menimbulkan kerusakan yang serius terhadap lingkungan. Program modernisasi perikanan contohya, yang bertujuan menigkatkan produksi hasil tangkapan nelayan menggunakan teknologi penangkapan yang semakin modern tidak disertai dengan sosialisasi pemahaman yang baik terhadap lingkungan kelautan. Hal ini berakibat fatal terhadap kelestarian lingkungan karena terjadi ekploitasi sumberdaya secara maksimal tanpa memperhatikan potensi lestari yang ada. Degradasi lingkungan pesisir dan laut yang manjadi ancaman bagi kelangsungan hidup masyarakat pesisir dan nelayan akibat faktorfaktor lain masih berlanjut hingga saat ini seperti misalnya pencemaran lingkungan perairan akibat limbah industri dan rumah tangga. Selain merusak potensi sumberdaya perairan, degradasi lingkungan ini juga berakibat buruk bagi kesehatan dan kelangsungan hidup manusia, terutama masyarakat pesisir.

Akses pemanfaatan teknologi yang terbatas. Semakin tingginya persaingan dalam pemanfaatan sumberdaya laut dan pesisir, menuntut 
masyarakat untuk memaksimalkan produksi mereka. Salah satu cara yang digunakan adalah dengan penggunaan teknologi. Keterbatasan pengetahuan dan kemampuan dalam penggunaan teknologi ini menjadi salah satu kendala dan pemicu adanya eksploitasi sumberdaya yang merusak potensi lestari dan berdampak negatif bagi lingkungan. Salah satu contohnya adalah penggunaan bom ikan dan potasium sianida untuk menangkap jenis-jenis ikan dengan nilai ekonomis tinggi di habitat terumbu karang telah merusak dan menimbulkan pencemaran lingkungan yang parah. Contoh lain adalah adanya kesenjangan penggunaan teknologi antara nelayan besar dan tradisional yang berakibat pada makin terdesaknya nelayan tradisional dalam persaingan pemanfaatan sumberdaya laut, sehingga banyak yang beralih profesi menjadi buruh nelayan atau buruh bangunan.

Kebijakan terkait Pengelolaan, Pengawasan Kelautan dan Pesisir ada beberapa kebijakan Peraturan Perundang-Undangan yang dapat dapat dijadikan landasan hukum:

1. Undang-undang Nomor 17 Tahun 1985 tentang Pengesahan United
Nations Convention on the Law of the Sea (UNCLOS), 1982

Konvensi PBB tentang

Hukum Laut (United Nations Convention on the Law of the Sea) 1982, disahkan dengan UndangUndang Nomor 17 Tahun 1985 tentang Pengesahan UNCLOS 1982. UNCLOS 1982 tidak mengatur secara khusus dalam pasalpasalnya tentang pengelolaan wilayah pesisir dan laut. Tetapi tersirat bahwa sumber kekayaan yang ada di laut memerlukan pengelolaan yang baik sesuai dengan prinsip-prinsip pembangunan berkelanjutan, tanpa merusak lingkungan laut, sehingga dapat digunakan untuk kemakmuran umat manusia. Pengaturan tentang pentingnya perlindungan dan pelestarian lingkungan laut diatur dalam UNCLOS 1982 Part XII tentang Protection and Preservation of the Marine Environment.

2. Undang-undang Nomor 6 Tahun 1996 Tentang Perairan Indonesia Undang-Undang Nomor 17 Tahun 1985 tentang Pengesahan United Nations Convention on the Law of the Sea (UNCLOS), 1982, membawa konsekuensi kepada 
NKRI untuk memperbarui ketentuan tentang Perairan Indonesia seperti diatur dalam Undang-undang Nomor 4/Prp/1960 tentang Perairan Indonesia dengan Undang-undang Nomor 6 Tahun 1996 tentang Perairan Indonesia dan disesuaikan dengan perkembangan rezim baru negara kepulauan sebagaimana di muat dalam Bab IV UNCLOS 1982.

Pengaturan khusus tentang pengelolaan wilayah pesisir dan laut tidak dijelaskan secara terinci, tetapi hanya di atur tersirat dalam Bab IV tentang Pemanfaatan, Pengelolaan, Perlindungan dan Pelestarian Lingkungan Perairan Indonesia. Hal ini sesuai dengan prinsip-prinsip sustainable development dalam pengelolaan sumberdaya di wilayah pesisir dan laut. Dalam Pasal 23 ayat (1) disebutkan bahwa: "Pemanfaatan, pengelolaan, perlindungan, dan pelestarian lingkungan perairan Indonesia dilakukan berdasarkan peraturan perundang-undangan nasional yang berlaku dan hukum internasional".

\begin{tabular}{lrr}
\multicolumn{1}{c}{ Sebagai } & upaya untuk \\
meningkatkan & pemanfaatan \\
sumberdaya alam & di & perairan
\end{tabular}

Indonesia, dijelaskan dalam Pasal 23 ayat (3), bahwa: "Apabila diperlukan untuk meningkatkan pemanfaatan, pengelolaan, perlindungan, dan pelestarian lingkungan perairan Indonesia sebagaimana dimaksud dalam ayat (10) dapat dibentuk suatu badan koordinasi yang ditetapkan dengan Keputusan Presiden."

3. Undang-Undang No. 11 Tahun 2006 Tentang Pemerintah Aceh

$$
\text { Bagian ketiga Undang- }
$$

Undang Pemerintah Aceh menyebutkan bahwa Pengelolaan Sumber Daya Alam terdapat dalam Pasal 156:

(1) Pemerintah Aceh dan pemerintah kabupaten/kota mengelola sumber daya alam di Aceh baik di darat maupun di laut wilayah Aceh sesuai dengan kewenangannya.

(2) Pengelolaan sebagaimana dimaksud pada ayat (1) meliputi perencanaan, pelaksanaan, pemanfaatan dan pengawasan kegiatan usaha yang dapat berupa eksplorasi, eksploitasi, dan budidaya.

(3) Sumber daya alam sebagaimana dimaksud pada ayat (1) meliputi bidang pertambangan yang terdiri atas pertambangan mineral, batu bara, panas bumi, bidang kehutanan, pertanian, perikanan, dan kelautan yang dilaksanakan dengan menerapkan prinsip 
transparansi dan pembangunan berkelanjutan.

$$
\text { Selanjutnya Bagian Kelima }
$$

Perikanan dan Kelautan Pasal 162 menyebutkan:

(1) Pemerintah Aceh dan pemerintah kabupaten/kota berwenang untuk mengelola sumber daya alam yang hidup di laut wilayah Aceh.

(2) Kewenangan untuk mengelola sumber daya alam yang hidup di laut sebagaimana dimaksud pada ayat (1) meliputi:

a. konservasi dan pengelolaan sumber daya alam di laut;

b. pengaturan administrasi dan perizinan penangkapan dan/atau pembudidayaan ikan;

c. pengaturan tata ruang wilayah laut, pesisir, dan pulau-pulau kecil;

d. penegakan hukum terhadap peraturan yang dikeluarkan atas wilayah laut yang menjadi kewenangannya;

e. pemeliharaan hukum adat laut dan membantu keamanan laut; dan

f. keikutsertaan dalam pemeliharaan kedaulatan Negara Kesatuan Republik Indonesia.

(3) Pemerintah Aceh dan pemerintah kabupaten/kota berwenang menerbitkan izin penangkapan ikan dan pengusahaan sumber daya alam laut lainnya di laut sekitar Aceh sesuai dengan kewenangannya.

(4) Pengelolaan sumber daya alam di wilayah laut sebagaimana dimaksud pada ayat (1), ayat
(2), dan ayat (3) dilakukan dengan memperhatikan prinsip-prinsip pembangunan berkelanjutan dan pelestarian lingkungan hidup.

4. Undang-Undang Nomor 17 Tahun 2007 tentang Rencana Pembangunan Jangka Panjang (RPJP) Nasional 2005-2025

Pengelolaan sumberdaya alam secara berkelanjutan merupakan bagian dari rencana pembangunan yang akan dilakukan oleh pemerintah sesuai RPJP Nasional Tahun 2005- 2025, tertuang dalam Bab II - huruf I yang mengatur mengenai Sumberdaya Alam dan Lingkungan Hidup. Dalam Bab II-huruf I dinyatakan bahwa sumber daya alam dan lingkungan hidup memiliki peran ganda, yaitu sebagai modal pembangunan dan sekaligus sebagai penopang sistem kehidupan. Adapun jasa-jasa lingkungan meliputi keanekaragaman hayati, penyerapan karbon, pengaturan secara alamiah, keindahan alam, dan udara bersih merupakan penopang kehidupan manusia.

Arah pembangunan untuk mengembangkan potensi sumber daya kelautan menurut Undang- 
Undang Nomor 17 Tahun 2007 tentang RPJP Nasional adalah pendayagunaan dan pengawasan wilayah laut yang sangat luas. Arah pemanfaatannya harus dilakukan melalui pendekatan multisektor, integratif, dan komprehensif agar dapat meminimalkan konflik dan tetap menjaga kelestariannya. Mengingat kompleksnya permasalahan dalam pengelolaan sumberdaya laut, pesisir, dan pulau-pulau kecil, pendekatan keterpaduan dalam kebijakan dan perencanaan menjadi prasyarat utama dalam menjamin keberlanjutan proses ekonomi, sosial, dan lingkungan sesuai dengan prinsip-prinsip yang terdapat dalam integrated coastal management.

5. Undang-Undang Nomor 27 Tahun 2007 tentang Pengelolaan Wilayah Pesisir dan Pulau-pulau Kecil Lahirnya UU No. 27 Tahun 2007 tentang Pengelolaan Wilayah Pesisir dan Pulau-Pulau Kecil merupakan sebuah bukti bahwa pemerintah mulai menyadari bahwa kekayaan laut harus dijaga kelestariannya dan dimanfaatkan sebesar-besarnya untuk kemakmuran rakyat secara langsung maupun tidak langsung untuk generasi sekarang dan generasi yang akan datang.

Menurut Pasal 1 angka 1 dinyatakan bahwa Pengelolaan Wilayah Pesisir dan Pulau-Pulau Kecil adalah suatu proses perencanaan, pemanfaatan, pengawasan, dan pengendalian Sumber Daya Pesisir dan PulauPulau Kecil antarsektor, antarapemerintah dan pemerintah daerah, antara ekosistem darat dan laut, serta antara ilmu pengetahuan dan manajemen untuk meningkatkan kesejahteraan masyarakat. Selanjutnya dalam Pasal 1 angka 2, Wilayah Pesisir adalah daerah peralihan antara ekosistem darat dan laut yang dipengaruhi oleh perubahan di darat dan laut.

Pasal 1 angka 4 menyatakan Sumber Daya Pesisir dan Pulau-Pulau Kecil adalah sumber daya hayati, sumber daya nonhayati; sumber daya buatan, dan jasa-jasa lingkungan; sumber daya hayati meliputi ikan, terumbu karang, padang lamun, mangrove dan biota laut lain; sumber daya nonhayati meliputi pasir, air laut, mineral dasar laut; sumber daya 
buatan meliputi infrastruktur laut yang terkait dengan kelautan dan perikanan, dan jasa-jasa lingkungan berupa keindahan alam, permukaan dasar laut tempat instalasi bawah air yang terkait dengan kelautan dan perikanan serta energi gelombang laut yang terdapat di wilayah pesisir. Berkaitan dengan definisi mengenai perairan pesisir dinyatakan dalam Pasal 1 angka 7, Perairan Pesisir adalah laut yang berbatasan dengan daratan meliputi perairan sejauh 12 (duabelas) mil laut diukur dari garis pantai, perairan yang menghubungkan pantai dan pulaupulau, estuari, teluk, perairan dangkal, rawa payau, dan laguna.

UU tentang Pengelolaan Wilayah Pesisir dan Pulau-Pulau Kecil bertujuan untuk melindungi, mengonservasi, merehabilitasi, dan memperkaya sumber daya pesisir dan laut secara berkelanjutan serta meningkatkan nilai sosial, ekonomi, dan budaya masyarakat melalui peran serta masyarakat dalam pemanfaatan sumber daya pesisir dan pulau-pulau kecil. Salah satu substansi penting dari UU ini, yaitu dilahirkannya Hak
Pengusahaan

Perairan

Pesisir (HP3).

Dalam Pasal 16 UU tentang

Pengelolaan Wilayah Pesisir dan

Pulau-Pulau Kecil dinyatakan

bahwa pemanfaatan

perairan pesisir meliputi pengusahaan atas permukaan laut dan kolom air sampai dengan permukaan dasar laut diberikan dalam bentuk HP3. HP3 ini dilahirkan karena sistem pemanfaatan yang ada sekarang ini terbukti tidak efektif dan belum meningkatkan taraf hidup masyarakat nelayan.

Dalam kenyatannya, HP3 bukanlah hal yang baru bagi masyarakat Indonesia, dalam UUPA, pernah diperkenalkan Hak Pemeliharaan dan Penangkapan Ikan (HPPI). Namun Peraturan Pemerintah tentang HPPI tidak pernah diterbitkan. Bahkan jauh sebelum itu, beberapa masyarakat tradisional di Indonesia telah mengembangkan tradisi pengelolaan perairan pesisir yang bersifat eksklusif. Berkembangnya pemanfaatan perairan pesisir dewasa ini, seperti budidaya mutiara dan rumput laut serta ekowisata bahari dan untuk 
memelihara pengakuan terhadap hak-hak adat. Pengakuan terhadap hak-hak adat terkait dengan HP3 sebagaimana tercantum dalam Pasal 17 yang menyatakan HP3 diberikan dalam luasan dan waktu tertentu dan pemberian HP3 wajib mempertimbangkan kepentingan kelestarian ekosistem pesisir dan pulau-pulau kecil, masyarakat adat, dan kepentingan nasional serta hak lintas damai bagi kapal asing.

Pemerintah memberikan wewenang kepada pemerintah daerah untuk menerbitkan HP3. Untuk dapat menerbitkan HP3, pemerintah daerah harus sudah terlebih dahulu memiliki rencana strategis, rencana zonasi, rencana pengelolaan, dan rencana aksi wilayah pesisir yang masingmasing ditetapkan dalam bentuk suatu Peraturan Daerah (Perda). Hal ini dimaksudkan untuk mengantisipasi munculnya konflik pemanfaatan setelah diberikannya HP3. Prioritas pertama penerima HP3 adalah masyarakat lokal atau adat yang secara turun temurun menguasai dan memanfaatkan perairan pesisir. Pemberian HP3 untuk komunitas ini tidak terbatas hanya untuk kegiatan ekonomi, namun juga dapat diberikan untuk kegiatan-kegiatan yang bersifat religius dan kultural.

Dalam Pasal 18 HP3 dapat diberikan kepada orang perseorangan warga negara Indonesia; badan hukum yang didirikan berdasarkan hukum Indonesia; atau masyarakat adat. Masyarakat hukum adat di berikan ruang dalam Undang-Undang ini untuk memiliki HP3. Diatur bahwa subyek hukum lain yang dapat diberikan HP3 adalah warga negara Indonesia dan badan hukum Indonesia. Oleh karena itu, perusahaan asing atau multinasional tidak dapat diberikan HP3.

Jangka waktu HP3 akan diberikan dengan mempertimbangkan karakteristik usaha danwaktu yang kondusif bagi tumbuhnya investasi. Jangka waktu pertama akan diberikan selama 20 (dua puluh) tahun dan dapat diperpanjang lagi masingmasing 20 (dua puluh) tahun sampai waktu yang tak terbatas sepanjang masih dimanfaatkan secara efektif. Selain itu, HP3 akan diberikan dalam bentuk sertifikat 
yang dapat beralih, dialihkan dan dapat dijadikanjaminan utang. HP3 akan berakhir karena jangka waktunya habis dan tidak diperpanjang lagi, ditelantarkan atau dicabut untuk kepentingan umum.

Penerbitan HP3 bertujuan untuk mendorong orang, kelompok masyarakat, atau pengusaha untuk memanfaatkan sumber daya perairan pada areal tepi laut hingga jarak 12 mil dari pantai. Pengaplingan pesisir untuk menopang HP3 dilakukan bersama-sama oleh pemerintah daerah, masyarakat pesisir, dan pengusaha. Pemberian HP3 memberikan kepastian hukum untuk berinvestasi sekaligus perlindungan kawasan. HP3 akan mendorong percepatan investasi di wilayah pesisir dan menguntungkan semua pihak. Pelaku usaha memiliki kepastian hukum dalammengembangkan usaha dan nelayan terlindungi dalam menangkap ikan di perairan.

Terdapat kelemahan dalam UU ini mengenai penerbitan HP3, yaitu hak pengelolaan pesisir itu belum mampu melindungi nelayan dan masyarakat pesisir terhadap kepentingan pemilik modal. Selain itu, HP3 tersebut akan mengapling laut untuk kegiatan usaha dikhawatirkan kian menggerus hak-hak masyarakat adat yang sekian lama termajinalkan. Setidaknya, ada tiga hal mendasar yang perlu dipertimbangkan ulang dalam pemberian hak tersebut. Pertama, aspek pemenuhan hak atas perlindungan dan keselamatan warga negara dari ancaman bencana. Sudah menjadi pengetahuan setiap orang, bahwa wilayah Indonesia terletak di sepanjang jajaran gunung api (yang dikenal dengan ring of fire), serta pertemuan tiga lempeng bumi, yang secara alamiah telah menyebabkan Indonesia rawan bencana.

Semua itu memberikan isyarat betaparentannya wilayah pesisir dan pulau-pulau kecil di Indonesia terhadap bencana. Kedua, menakar untuk siapa sebenarnya sertifikat HP3 diberikan. Dengan komposisi kemiskinanan yang masih mendominasi, serta taraf pendidikan yang juga masih sangatrendah, menjadi tidak relevan bagi masyarakat nelayan 


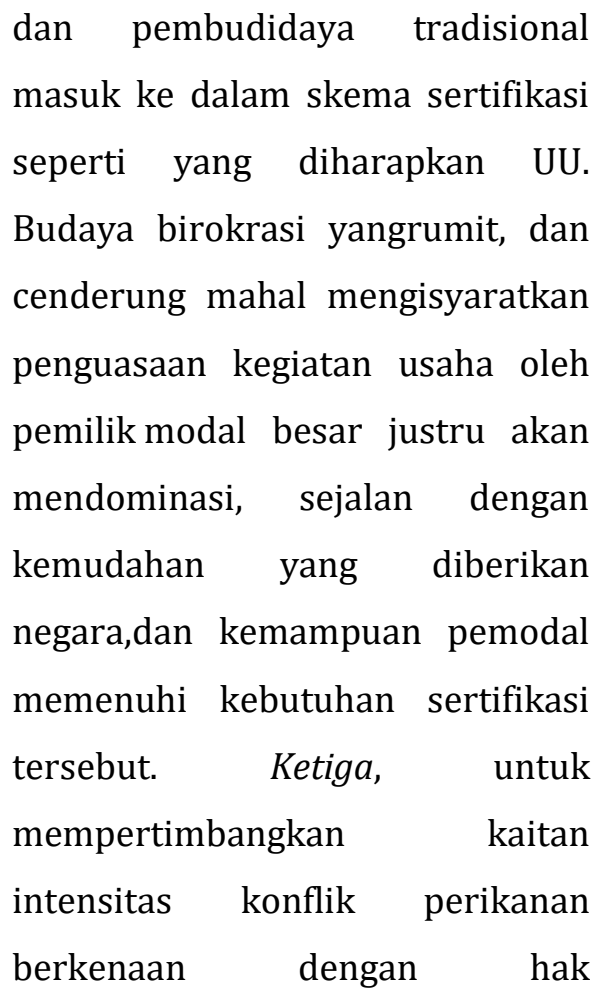
kepemilikan. Hak kepemilikan mencakup pertanyaan filosofis yang telah berlangsung sejak lama mengenaiaspek legal, sejarah dan/atau kepemilikan, akses dan kontrol perikanan. Konflik inisendiri cenderung, di antaranya, disebabkan perbedaan kepentingan terhadap beberapa bentuk kepemilikan perikanan, di antaranya: openaccess, manajemen terpusat, hak pengelolaan kawasan, pengelolaan berbasis masyarakat, kuota individu, dan privatisasi.

Pengelolaan sumberdaya

wilayah pesisir dan laut belum terintegrasi dengan kegiatan pembangunan dari berbagai sektor dan daerah. Hal ini dapat dilihat dari peraturan perundang undangan tentang pemanfaatan sumberdaya pesisir dan laut selama ini lebih berorientasi kepada eksploitasi sumberdaya pesisir dan laut tanpa memperhatikan kelestarian sumberdayanya, dan belum mampu untuk mengeliminasi faktor-faktor penyebab kerusakan lingkungan. Seperti disebutkan dalam Penjelasan Undang-undang Nomor 27 Tahun 2007 tentang Pengelolaan Wilayah Pesisir dan Pulau-pulau Kecil (PWP-PK), bahwa : "Norma-norma pengelolaan wilayah pesisir disusun dalam lingkup perencanaan, pemanfaatan, pengelolaan, pengendalian, dan pengawasan, dengan memperhatikan norma-norma yang diatur dalam peraturan perundang-undangan lainnya." Sebagai negara hukum, pelaksanaan pengembangan sistem pengelolaan wilayah pesisir dan laut sebagai bagian dari pembangunan berkelanjutan harus sesuai dengan norma diberi dasar hukum yang jelas, tegas, dan 
menyeluruh guna menjamin kepastian hukum bagi upaya pengelolaan wilayah pesisir. Undang-undang Nomor 27 Tahun 2007 tentang PWP-PK, dalam Pasal 3 tentang Asas dan Tujuan, menyatakan bahwa: "Pengelolaan Wilayah Pesisir dan Pulau-Pulau Kecil berasaskan:
a) keberlanjutan;
b) konsistensi;
c) keterpaduan;
d) kepastian hukum;
e) kemitraan;
f) pemerataan;
g) peran serta masyarakat;
h) keterbukaan;
i) desentralisasi;
j) akuntabilitas; dan
k) keadilan."

Asas-asas yang terdapat dalam Undang-undang Nomor 27 Tahun 2007 tentang PWP-PK merupakan implementasi dari prinsip-prinsip dasar yang terdapat dalam integrated coastal management. Implementasi dari prinsip-prinsip tersebut dalam Undang-undang Nomor 27 Tahun 2007 tentang PWP-PK disesuaikan dengan kondisi geografis dan masyarakat di Indonesia. Konsistensi dan keterpaduan dalammelaksanakan pengelolaan wilayah pesisir sesuai dengan asasasas tersebut memerlukan pengawasan dan evaluasi, baik oleh Pemerintah atau stakeholders.

$$
\text { Sesuai dengan prinsip- }
$$
prinsip integrated coastal management, sebagaimana diatur dalam Pasal 4 Undang-undang Nomor 27 Tahun 2007 tentang PWP-PK pengelolaan wilayah pesisir melibatkan banyak sektor dan sumberdaya alam baik hayati maupun non hayati, sehingga pelaksanaannya dilakukan dengan cara menciptakan keharmonisan dan sinergi antara Pemerintah dan Pemerintah Daerah, mengikutsertakan peran serta masyarakat dan lembaga pemerintah.

$$
\text { Ketentuan tentang Hak }
$$

Pengusahaan Perairan Pesisir tersebut akan menimbulkan perbedaan penafsiran jika dikaitkan dengan ketentuan tentang hak-hak yang terdapat dalam Undang-undang Nomor 5 Tahun 1960 tentang Pokok-Pokok Agraria Bab II Bagian 1, Pasal 16 Ayat (1) dan Ayat (2). Menurut Undang-undang Nomor 5 Tahun 1960 tentang Pokok-Pokok 
Agraria, hak atas tanah tidak meliputi pemilikan kekayaan alam yang terkandung di dalam tubuh bumi di bawahnya. Seperti yang dinyatakan dalam Pasal 8 Undangundang Nomor 5 Tahun 1960 tentang Pokok-Pokok Agraria, bahwa pengambilan kekayaan alam yang terkandung dalam bumi, air dan ruang angkasa perlu diatur. Pada dasarnya kekayaan sumberdaya alam di wilayah pesisir juga merupakan bagian dari kekayaan alam yang di maksud dalam Pasal 8 Undang-undang Nomor 5 Tahun 1960 tentang Pokok-Pokok Agraria. Tetapi Penjelasan Pasal 8 Undang-undang Nomor 5 Tahun 1960 tentang Pokok- Pokok Agraria pada dasarnya menyebutkan bahwa hak-hak atas tanah itu hanya memberi hak atas permukaan bumi, maka wewenang-wewenang yang bersumber daripadanya tidaklah mengenai kekayaankekayaan alam yang terkandung dalam tubuh bumi, air dan ruang angkasa, sehingga pengambilan kekayaan tersebut memerlukan pengaturan tersendiri.

Mengacu pada prinsip 5 dan 6 dari integrated coastal management, untuk menghindari perbedaan penafsiran, pembagian dan penentuan batas wilayah pesisir terkait dengan pengelolaan wilayah pesisir diperlukan upaya integrasi dan koordinasi dengan sektor lain yang terkait, terutama dalam konservasi sumberdaya alam milik bersama (common property resources) sehingga tidak menimbulkan konflik dalam pelaksanaannya.

6. Undang-Undang Nomor 32 Tahun 2009 tentang Perlindungan dan Pengelolaan Lingkungan Hidup

$$
\text { UU tentang Perlindungan }
$$

dan Pengelolaan Lingkungan Hidup ini mewajibkan Pemerintah dan pemerintah daerah untuk membuat kajian lingkungan hidup strategis (KLHS) untuk memastikan bahwa prinsip pembangunan berkelanjutan telah menjadi dasar dan terintegrasi dalam pembangunan suatu wilayah dan/atau kebijakan, rencana, dan/atau program.

Dengan perkataan lain, hasil KLHS harus dijadikan dasar bagi kebijakan, rencana dan/atau program pembangunan dalam suatu wilayah. Apabila hasil KLHS menyatakan bahwa daya dukung 
dan daya tampung sudah terlampaui, kebijakan, rencana, dan/atau program pembangunan tersebut wajib diperbaiki sesuai dengan rekomendasi KLHS dan segala usaha dan/atau kegiatan yang telah melampaui daya dukung dan daya tampung lingkungan hidup tidak diperbolehkan lagi.

Ilmu pengetahuan dan teknologi telah meningkatkan kualitas hidup dan mengubah gaya hidup manusia. Pemakaian produk berbasis kimia telah meningkatkan produksi limbah bahan berbahaya dan beracun. Hal itu menuntut dikembangkannya sistem pembuangan yang aman dengan risiko yang kecil bagi lingkungan hidup, kesehatan, dan kelangsungan hidup manusia serta makhluk hidup lain.

Di samping menghasilkan produk yang bermanfaat bagi masyarakat, industrialisasi juga menimbulkan dampak, antara lain, dihasilkannya limbah bahan berbahaya dan beracun, yang apabila dibuang ke dalam media lingkungan hidup dapat mengancam lingkungan hidup, kesehatan, dan kelangsungan hidup manusia serta makhluk hidup lain.

Dengan menyadari hal tersebut, bahan berbahaya dan beracun beserta limbahnya perlu dilindungi dan dikelola dengan baik. Wilayah Negara Kesatuan Republik Indonesia harus bebas dari buangan limbah bahan berbahaya dan beracun dari luar wilayah Indonesia.

Menyadari potensi dampak negatif yang ditimbulkan sebagai konsekuensi dari pembangunan, terus dikembangkan upaya pengendalian dampak secara dini. Analisis mengenai dampak lingkungan (amdal) adalah salah satu perangkat preemtif pengelolaan lingkungan hidup yang terus diperkuat melalui peningkatkan akuntabilitas dalam pelaksanaan penyusunan amdal dengan mempersyaratkan lisensi bagi penilai amdal dan diterapkannya sertifikasi bagi penyusun dokumen amdal, serta dengan memperjelas sanksi hukum bagi pelanggar di bidang amdal.

Amdal juga menjadi salah satu persyaratan utama dalam memperoleh izin lingkungan yang mutlak dimiliki sebelum diperoleh 
izin usaha. Upaya preventif dalam rangka pengendalian dampak lingkungan hidup perlu dilaksanakan dengan mendayagunakan secara maksimal instrumen pengawasan dan perizinan. Dalam hal pencemaran dan kerusakan lingkungan hidup sudah terjadi, perlu dilakukan upaya represif berupa penegakan hukum yang efektif, konsekuen, dan konsisten terhadap pencemaran dan kerusakan lingkungan hidup yang sudah terjadi.

Sehubungan dengan hal tersebut, perlu dikembangkan satu sistem hukum perlindungan dan pengelolaan lingkungan hidup yang jelas, tegas, dan menyeluruh guna menjamin kepastian hukum sebagai landasan bagi perlindungan dan pengelolaan sumber daya alam serta kegiatan pembangunan lain.

UU ini juga mendayagunakan berbagai ketentuan hukum, baik hukum administrasi, hukum perdata, maupun hukum pidana. Ketentuan hukum perdata meliputi penyelesaian sengketa lingkungan hidup di luar pengadilan dan di dalam pengadilan. Penyelesaian sengketa lingkungan hidup di dalam pengadilan meliputi gugatan perwakilan kelompok, hak gugat organisasi lingkungan, ataupun hak gugat pemerintah. Melalui cara tersebut diharapkan selain akan menimbulkan efek jera juga akan meningkatkan kesadaran seluruh pemangku kepentingan tentang betapa pentingnya perlindungan dan pengelolaan lingkungan hidup demi kehidupan generasi masa kini dan masa depan.

Penegakan hukum pidana dalam UU ini memperkenalkan ancaman hukuman minimum di samping maksimum, perluasan alat bukti, pemidanaan bagi pelanggaran baku mutu, keterpaduan penegakan hukum pidana, dan pengaturan tindak pidana korporasi. Penegakan hukum pidana lingkungan tetap memperhatikan asas ultimum remedium yang mewajibkan penerapan penegakan hukum pidana sebagai upaya terakhir setelah penerapan penegakan hukum administrasi dianggap tidak berhasil. Penerapan asas ultimum remedium ini hanya berlaku bagi tindak pidana formil 
tertentu, yaitu pemidanaan

upaya pemantauan

terhadap pelanggaran baku mutu air limbah, emisi, dan gangguan.

Adanya penguatan yang terdapat dalam UU ini tentang prinsip-prinsip perlindungan dan pengelolaan lingkungan hidup yang didasarkan pada tata kelola pemerintahan yang baik karena dalam setiap proses perumusan dan penerapan instrumen pencegahan pencemaran dan/atau kerusakan lingkungan hidup serta penanggulangan dan penegakan hukum mewajibkan pengintegrasian aspek transparansi, partisipasi, akuntabilitas, dan keadilan. Selain itu, UU ini juga mengatur:
a. keutuhan unsur-unsur pengelolaan lingkungan hidup;
b. kejelasan kewenangan antara pusat dan daerah;
c. penguatan pada upaya pengendalian lingkungan hidup;

d. penguatan instrumen pencegahan pencemaran dan/atau kerusakan lingkungan hidup, yang meliputi instrumen kajian lingkungan hidup strategis, tata ruang, baku mutu lingkungan hidup, kriteria baku kerusakan lingkungan hidup, amdal, upaya pengelolaan lingkungan hidup dan 
Beberapa hal yang terkait dengan tanah dalam UU ini terdapat dalam BAB IV tentang Pemanfaatan, yaitu dalam Pasal 12 mengenai pemanfaatan sumber daya alam, dan dalam Bab V tentang Pengendalian, yaitu dalam paragraf 4 mengenai kriteria kerusakan lingkungan hidup, khususnya Pasal 21 ayat (3) huruf a "Kriteria baku kerusakan ekosistem meliputi kriteria baku kerusakan tanah untuk produksi biomassa, yang dimaksud dengan "produksi biomassa" adalah bentuk-bentuk pemanfaatan sumber daya tanah untuk menghasilkan biomassa. Yang dimaksud dengan "kriteria baku kerusakan tanah untuk produksi biomassa" adalah ukuran batas perubahan sifat dasar tanah yang dapat ditenggang berkaitan dengan kegiatan produksi biomassa.

7. Undang-Undang No. 23 Tahun 2014 Tentang Pemerintah Daerah Berdasarkan UndangUndang Nomor 23 Tahun 2014, bahwa pemerintah daerah berwenang untuk mengatur dan mengurus sendiri urusan pemerintahannya menurut asas otonomi dan tugas pembantuan.
Pemberian otonomi luas kepada daerah diarahkan untuk mempercepat terwujudnya kesejahteraan masyarakat melalui peningkatan pelayanan, pemberdayaan dan peran serta masyarakat.

Sejak diberlakukannya Undang-Undang Nomor 23 Tahun 2014 tentang Pemerintahan Daerah, Pemerintah Pusat belum pernah memberikan otonomi yang nyata dalam pemanfaatan sumberdaya pesisir di wilayah pesisir. Status Quo kewenangan daerah ini tidak menjadi perhatian Pemerintah, karena kegiatan ekonomi yangberlangsung di wilayah pesisir dilakukan berdasarkan pendekatan sektoral yang menguntungkan instansi sektoral dan usaha tertentu.

Kewenangan Pemerintah Pusat dalam mengelola sumberdaya di wilayah ini merupakan kewenangan atribusi yang langsung bersumberkan pada Undang-undang Dasar 1945 Pasal 33, Undang-undang Nomor 5 Tahun 1983 tentang Zona Ekonomi Eksklusif Indonesia, Undangundang Nomor 1 Tahun 1973 tentang Landas Kontinen 
Indonesia, Undang-undang Nomor

6 Tahun 1996 tentang Perairan Indonesia, dan Undang-Undang Nomor 17 Tahun 1985 tentang Pengesahan UNCLOS 1982. Perluasan kewenangan pengelolaan wilayah pesisir diberikan kepada Kabupaten/Kota dan Provinsi untuk mengelola sumberdaya laut dan daratan dalam wilayah hukumnya. Hal ini diperkuat dengan Undang-Undang Nomor 33 Tahun 2004 tentang Perimbangan Keuangan Antara Pemerintah Pusat dan Pemerintah Daerah Pasal 6, yaitu: "Pendapatan asli daerah bersumber dari: a) Pajak daerah; b) Retribusi daerah; c) hasil pengelolaan kekayaan daerah yang dipisahkan; dan d) lain-lain PAD yang sah."

Pendapatan asli daerah juga dapat diperoleh dari dana perimbangan, seperti dijelaskan dalam Pasal 11 tentang dana bagi hasil. Ayat (1) dari Pasal 11 menyebutkan bahwa dana bagi hasil bersumberkan dari pajak dan "sumber daya alam". Pembagian kewenangan kepada pemerintah daerah atas wilayah laut sebagaimana dimaksud UndangUndang Nomor 23 Tahun 2014 tentang Pemerintahan Daerah, secara yuridis tidak mengubah wilayah perairan Indonesia sebagaimana diatur dalam Undang- Undang Nomor 6 Tahun 1996 tentang Perairan Indonesia. Kewenangan yang diberikan oleh Undang-Undang Nomor 23 Tahun 2014 tentang Pemerintahan Daerah untuk melaksanakan pengelolaan sumberdaya kelautan di wilayah kewenangannya disertai dengan kewajiban untuk memelihara kelestarian lingkungannya.

Dalam UU No. 23 Tahun 2014 Tentang Pemerintah Daerah, Pasal 12 ayat (3) menyatakan bahwa Urusan Pemerintahan Pilihan sebagaimana dimaksud dalam Pasal 11 ayat (1) meliputi:
a. kelautan dan perikanan;
b. pariwisata;
c. pertanian;
d. kehutanan;
e. energi dan sumber daya mineral;
f. perdagangan;
g. perindustrian; dan
h. transmigrasi.

(6) Penentuan Daerah kabupaten/kota penghasil untuk penghitungan bagi hasil kelautan adalah hasil kelautan yang berada 
dalam batas wilayah 4 (empat) mil diukur dari garis pantai ke arah laut lepas dan/atau ke arah perairan kepulauan.

8. Peraturan Pemerintah Nomor 19 Tahun 1999 tentang Pengendalian Pencemaran dan/atau Perusakan Laut

Peraturan Pemerintah ini mewajibkan setiap orang atau penanggung jawab usaha dan/atau kegiatan untuk melakukan upaya pencegahan dan bertanggung jawab terhadap perusakan/pencemaran laut. Ketentuan dalam Bab $\mathrm{V}$ tentang Penanggulangan Pencemaran dan/atau Perusakan Laut, dalam Pasal 15 menetapkan bahwa: "Setiap orang atau penanggung jawab usaha dan/atau kegiatan yang mengakibatkan pencemaran dan/atau perusakan laut wajib melakukan penanggulangan pencemaran dan/atau perusakan laut yang diakibatkan oleh kegiatannya." Pemanfaatan secara berlebihan terhadap sumberdaya di wilayah pesisir tanpa mengindahkan kelestarian lingkungan pesisir, akan mengakibatkan rusaknya ekosistem di wilayah pesisir.
9. Peraturan Pemerintah Nomor 38 Tahun 2007 tentang Pembagian Urusan Pemerintahan Antara Pemerintah, Pemerintahan Daerah Provinsi, dan Pemerintahan Daerah Kabupaten/Kota Kewenangan Pemerintah dalam hal pengelolaan sumberdaya alam diatur dalam Peraturan Pemerintah Republik Indonesia Nomor 38 Tahun 2007 tentang Pembagian Urusan Pemerintahan Antara Pemerintah, Pemerintahan Daerah Provinsi, dan Pemerintahan Daerah Kabupaten/Kota (selanjutnya disebut Peraturan Pemerintah Nomor 38 Tahun 2007).

Peraturan Pemerintah Nomor 38 Tahun 2007 mengatur mengenai Urusan pemerintahan yang menjadi kewenangan Pemerintahan Daerah terbagi dalam urusan wajib dan urusan pilihan. Pengelolaan wilayah pesisir dan laut merupakan bagian dari kelautan dan perikanan, yang dalam ketentuan ini merupakan bagian dari urusan pilihan yang menjadi kewenangan Pemerintahan Daerah. Urusan pemerintahan yang menjadi kewenangan Pemerintah Provinsi 
dalam pengelolaan wilayah pesisir hanya terbatas pada fungsi pemerintahan yang bersifat lintas Kabupaten/Kota dan untuk menghindari konflik kepentingan antar Kabupaten/Kota serta kewenangan yang tidak/belum dapat dilaksanakan oleh Pemerintah Daerah Kabupaten/Kota.

\section{KESIMPULAN}

Dari analisis pada bab-bab sebelumnya, maka dapat disimpulkan bahwa: Dalam pelaksanaan pengelolaan sumberdaya pesisir dan laut di pada hakikatnya ditujukan untuk memberdayakan sosial ekonomi masyarakat maka masyarakat seharusnya memiliki kekuatan besar untuk mengatur dirinya sendiri dalam pengelolaan sumberdaya pesisir dan laut di era otonomi ini. Proses peralihan kewenangan dari pemerintah ke masyarakat harus dapat diwujudkan. Namun ada beberapa hal yang masih menjadi tanggung jawab pemerintah seperti soal kebijakan fiskal sumberdaya, pembangunan sarana dan prasarana, penyusunan tata ruang pesisir, serta perangkat hukum pengelolaan sumberdaya. Meski hal tersebut menjadi bagian dari kewenangan pemerintah, namun tidak berarti masyarakat tidak memiliki kontribusi dan partisipasi dalam setiap formulasi kebijakan. Dengan adanya kontribusi dan partisipasi masyarakat maka kebijakan yang diformulasikan tersebut akan lebih menyentuh persoalan yang sebenarnya dan tidak merugikan kepentingan publik.

\section{DAFTAR PUSTAKA}

Abrar Saleng, 2004, Hukum Pertambangan, Penerbit UII Press, Yogyakarta

Agenda 21 Indonesia, Publikasi Awal, Strategi Nasional Untuk Pembangunan Berkelanjutan, Kantor Menteri Negara Lingkungan Hidup, Juli, 1997

Arifin Rudiyanto, Kerangka Kerjasama Dalam Pengelolaan Sumberdaya Pesisir dan Laut, Makalah Disanpaikan pada Sosialisasi Nasional Program MFCDP, 22 September 2004

Bali Plan of Action, "Towards Healthy Oceans and Coast for the SustainableGrowth and Prosperity of the Asia-Paicific Community," Joint Ministerial Statement, the 2nd APEC Ocean-Related Ministerial Meeting (AOMM2), Bali, 16-17 September 2005 
Churchill V. Lowe, The Law of the Sea, Juris Publishing, third edition, 1999

Danial Thaib, Evaluasi Kebijakan Pengelolaan Kawasan Pantai Utara Kabupaten Bekasi Dalam Peningkatan Kesejahteraan Masyarakat Pesisir, Dalam Jurnal Green Growth dan Manajemen Lingkungan, Vol. 1 Edisi Desember 2012

Dina Sunyowati, Pengaturan Pengelolaan Wilayah Pesisir dan Laut Di Indonesia, Artikel Ilmiah, Departemen Hukum Internasional, Fakultas Hukum, Universitas Airlangga

Peter Mahmud Marzuki, Penelitian Hukum, Prenada Media, Jakarta, 2005

Rohmin Dahuri, Paradigma Baru Pembangunan Indonesia Berbasis Kelautan, Orasi Ilmiah, Institut Pertanian Bogor, 2003

http://hukum.bung hatta.ac.id/ tulisan. php? dw.8,Artikel perlindungan Kawasan Pesisir dan Kelautan 